\title{
E-LEARNING BERCOCOK TANAM HIDROPONIK DENGAN METODE ASYNCHRONOUS LEARNING DAN DYNAMIC INTELLECTUAL LEARNING BERBASIS WEB
}

\author{
${ }^{1}$ Hadi Wibowo, ${ }^{2}$ Supriyadi, ${ }^{3}$ Dedih \\ 1,2 STMIK Kharisma Karawang, Teknik Informatika \\ ${ }^{3}$ STMIK Kharisma Karawang, Sistem Informasi \\ 11wibowo.hadi01@gmail.com, ${ }^{2}$ fnfcreator@stmik-kharisma.ac.id, ${ }^{3}$ dedihthea@gmail.com \\ Jl. Pangkal Perjuangan KM 1 ByPass Karawang 41316
}

\begin{abstract}
ABSTRAK
E-learning sistem bercocok tanam hidroponik merupakan suatu media pembelajaran yang digunakan untuk mempermudah pembelajaran bagi masyarakat umum. Ada beberapa kendala bagi masyarakat ketika akan mempelajari sistem bercocok tanam hidroponik misalnya, terbatasnya informasi tentang hidroponik, beberapa dari alamat situs hanya memberikan informasi mengenai hidroponik, yaitu pengenalan hidroponik, tahapan budidaya hidroponik, pembuatan dan pengaturan pemberian nutrisi, dan belum ada situs yang memberikan penjelasan secara rinci tentang apa saja bahan yang dibutuhkan dan berapa besar biayanya, padahal hal ini penting bagi orang yang ingin memulai usaha dalam bidang ini. Untuk mempermudah pembelajaran maka dibutuhkan e- learning dengan metode yang digunakan adalah metode Asynchronous Learning atau disebut juga dengan "tidak pada waktu yang bersamaan" serta Dynamic Intellectual Learning yang memberikan kesempatan kepada pengguna (peserta didik) untuk mengakses materi sesuai dengan kemampuannya masing-masing. Jadi seseorang dapat mengambil pelatihan pada waktu yang berbeda dengan pengajar memberikan pelatihan serta mendapat materi sesuai dengan kemampuannya. Model analisis yang digunakan dalam penelitian ini menggunakan pendekatan berorientasi objek dengan metode pengembangan sistemnya adalah System Development Life Cycle (SDLC) Waterfall. E-learning yang dikembangkan merupakan aplikasi berbasis web yang bisa diakses masyarakat umum secara luas, diharapkan untuk membantu masyarakat dalam mendapatkan pembelajaran hidroponik kapanpun, di manapun, dan sesuai dengan kemampuan masing-masing yang dimiliki.
\end{abstract}

Kata kunci : E-learning, Hidroponik, Asynchronous Learning, Dynamic Intellectual Learning, SDLC Waterfall.

\section{PENDAHULUAN}

E-Learning atau electronic learning semakin dikenal sebagai salah satu media pembelajaran yang semakin banyak digunakan dalam dunia pendidikan saat ini, karena e-learning memanfaatkan teknologi informasi sebagai media komunikasi antara pengajar dengan peserta belajarnya. E-Learning semakin berkembang karena teknologi membuat proses pembelajaran dapat dilakukan lebih efisien dilihat dari segi waktu, jarak, dan biaya (Putri, 2013). Sifat dari teknologi informasi dan komunikasi adalah kemampuan untuk memungkinkan mengakses informasi secara fleksibel, akses yang fleksibel itu mengenai akses dan penggunaan informasi pada waktu dan tempat yang sesuai untuk peserta didik (Naidu, 2006). Sifat yang fleksibel merupakan kelebihan yang utama dari e-learning, keuntungannya adalah mendapatkan pelajaran kapanpun dan di manapun, dan tersedia kapan dan dimana saat dibutuhkan (Vecchio, 2006). Untuk membangun media pembelajaran yang fleksibel, sistem pembelajaran e-learning memiliki model interaksi yang berbeda dengan sistem pembelajaran konvensional, dimana interaksi yang terjadi dilakukan melalui media komunikasi yang memanfaatkan teknologi internet. Interaksi yang baik antar agen yang terlibat di dalam sebuah sistem menjadi faktor yang sangat penting demi tercapainya tujuan yang telah ditetapkan (Putri, 2013). Ada beberapa metode interaksi dalam e-learning, diantaranya adalah metode asynchronous learning. Metode asynchronous learning adalah interaksi yang dapat terjadi pada waktu 
yang tidak bersamaan, jadi peserta dapat mengambil pembelajaran pada waktu yang berbeda dengan pengajar memberikan materi pembelajaran. Pembelajaran ini lebih populer di dunia e-learning karena memberikan keuntungan lebih bagi peserta, yaitu dapat mengakses pembelajaran atau pelatihan kapanpun dan di manapun (Susanti, 2008). Serta untuk mengidentifikasi kemampuan masing- masing pengguna atau peserta didik yaitu menggunakan Model Dynamic Intellectual Learning (DIL). DIL akan memberikan kesempatan kepada pengguna (peserta didik) untuk mengakses materi sesuai dengan intelektual atau kemampuannya masing-masing. Sehingga peserta didik yang memiliki kemampuan lebih dibandingkan dengan yang lainnya dan memiliki kesempatan mengeksplorasi materi lebih banyak dan lebih cepat, dimana masing-masing peserta didik tidak harus menghadapi materi yang sama (Dantes, 2010). E-learning digunakan untuk pembelajaran formal atau tidak formal, pada pembelajaran tidak formal seperti pembelajaran pada pertanian atau cara bercocok tanam.

Saat ini telah dikenal cara bercocok tanam secara hidroponik, yaitu budidaya pertanian tanpa menggunakan media tanah, sehingga hidroponik merupakan aktivitas pertanian yang dijalankan dengan mengunakan air, kerikil, pasir, sekam bakar, dan sebagainya yang dicampur dengan larutan nutrisi sebagai media untuk menggantikan tanah, sehingga sistem bercocok tanam dengan hidroponik dapat memanfaatkan lahan yang sempit. Pertanian dengan sistem hidroponik memang tidak memerlukan lahan yang luas dalam pelaksanaannya, tetapi dalam skala bisnis pertanian hidroponik layak untuk dipertimbangkan luasnya. Semua jenis tanaman bisa ditanam dengan sistem hidroponik, golongan tanaman yang biasa ditanam dengan media tersebut adalah tanaman sayur, tanaman buah, tanaman hias, dan tanaman obat-obatan (Roidah, 2014).

Ada beberapa situs di internet yang memberikan informasi tentang hidroponik, isi dari alamat situs tersebut diantaranya adalah memberikan informasi mengenai hidroponik, yaitu pengenalan hidroponik, tahapan budidaya hidrponik, pembuatan dan pengaturan pemberian nutrisi. Adapun dari situs-situs yang telah ada tersebut hanya memberikan informasi secara garis besar saja. Belum ada situs yang memberikan penjelasan secara rinci tentang apa saja bahan yang dibutuhkan dan berapa besar biaya produksinya, padahal hal ini penting bagi orang yang ingin memulai usaha dalam bidang ini (Amalia, 2009). Untuk memenuhi kebutuhan masyarakat akan informasi mengenai sistem bercocok tanam hidroponik dan menyediakan sebuah forum diskusi yang dapat memberikan berbagai informasi, serta menjelaskan berbagai cara bercocok tanam hidroponik, maka dibutuhkan sebuah e-learning dengan menggunakan sebuah metode asynchronous learning dan dynamic intellectual learning serta dengan menggunakan metode pengembangan sistem System Development Life Cycle (SDLC) Waterfall (Satzinger dkk, 2010) untuk membantu masyarakat dalam mendapatkan pembelajaran hidroponik kapanpun, di manapun, dan sesuai dengan kemampuan masing-masing yang dimiliki peserta.

\section{METODE PENELITIAN}

Metode penelitian yang digunakan adalah metode SDLC Waterfall yaitu suatu metodologi pengembangan perangkat lunak yang mengusulkan pendekatan kepada perangkat lunak sistematik dan sekuensial yang mulai pada Project Planning phase, Analysis phase, Design phase, Implementation phase dan Support Phase (Satzinger dkk, 2010).

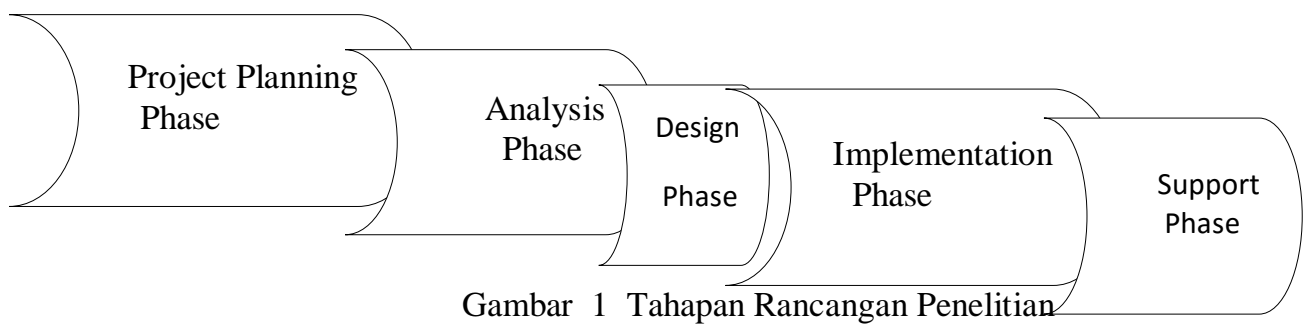

\section{PEMBAHASAN}

\subsection{Project Planning Phase}

Pada tahapan perencanaan dihasilkan rincian setiap aktivitas yang dilakukan. Adapun hasil dari tahapan ini adalah :

1. Identifikasi Masalah

Berdasarkan dari identifikasi masalah maka dihasilkan e-learning bercocok tanam hidroponik dengan 
metode Asynchronous Learning dan Dynamic Intellectual Learning (DIL) untuk membantu masyarakat umum mempelajari bercocok tanam hidroponik.

2. Pengumpulan data

Data-data bercocok tanam hidroponik yang meliputi :

Tabel 3.1 Materi Hidroponik

\begin{tabular}{lll}
\hline No. & Tingkatan Materi & Materi Hidroponik \\
\hline 1. & Tingkat Dasar & a. Sistem-sistem hidroponik \\
& & b. Media tanam hidroponik \\
& & c. Alat dan Bahan yang dibutuhkan
\end{tabular}

2. Tingkat Memulai
a. Persemaian
b. Penanaman
c. Pemeliharaan
d. Panen
e. Mengatur kadar air
f. Membuat larutan nutrisi hidroponik

3. Tingkat Lanjutan
a. Budidaya kangkung dan selada hijau hidroponik sistem rakit apung
b. Budidaya pakchoy, bayam, dan kangkung hidroponik sistem sumbu
c. Budidaya pakchoy, sawi caisim, selada hijau dan selada merah hidroponik sistem nutrient film technique (nft).
d. Budidaya pakchoy dan selada hijau hidroponik sistem deep flow technique (dft)
e. Budidaya kangkung dan bayam hijau hidroponik sistem pasang surut pada pipa pvc
f. Budidaya tomat hidroponik
g. Analisis usaha

3. Menganalisis Teori

Menganalisis teori dari e-learning ini adalah dengan menganalisis dari metode Asynchronous Learning yang digunakan sebagai media atau model interaksi pembelajaran dan DIL sebagai proses pemilihan materi yang sesuai dengan pengguna, serta untuk pengembangan sistem digunakan metode System Development Life Cycle (SDLC) Waterfall.

4. Pembuatan Jadwal

5. Mencari Solusi

Solusi untuk metode yang sesuai adalah menggunakan metode Asynchronous Learning dan DIL, karena metode Asynchronous Learning bisa melakukan pengajaran secara waktu yang tidak bersamaan, kapanpun dan di manapun,serta metode DIL untuk mengidentifikasi kemampuan dasar pengguna atau learner.

6. Mendefinisikan kebutuhan

Penggunaan Hardware laptop/notebook dan printer. Software Linux Ubuntu 14.04, Geany, LibreOffice Writer, LibreOffice Impress, Apache2, PHP, MySql, Firefox web browser, Dia Diagram.

\subsection{Analysis Phase}

\subsubsection{Analisis Metode Asynchronous Learning dan DIL}

Pada tahap ini dilakukan analisis terhadap metode Asynchronous Learning agar bisa melakukan pengajaran secara waktu yang tidak bersamaan, dan DIL untuk 
mengidentifikasi kemampuan dasar dari learner (Dantes, 2010), yang digambarkan pada arsitektur berikut :

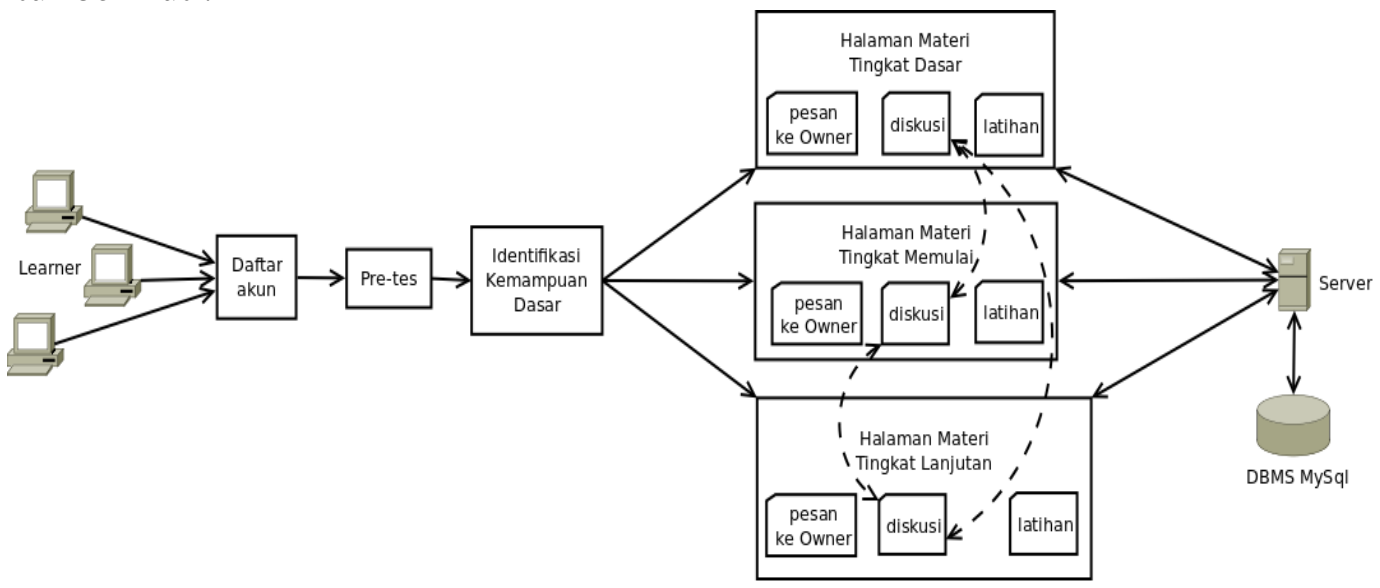

Gambar 3.1 Arsitektur e-learning

Adapun langkah-langkah yang dilakukan dalam metode tersebut adalah sebagai sebagai berikut:

1. Melakukan pre-tes

2. Mengidentifikasi dan menampilkan materi sesuai kemampuan dasar

3. Mengambil materi yang diberikan sistem

4. Melakukan latihan soal

5. Melakukan diskusi umum

6. Mengirim pesan kepada Owner

\subsubsection{Analisis Sistem}

\subsubsection{Use Case Diagram}

Berikut ini diagram use case yang menjelaskan interaksi di dalam e-learning bercocok tanam hidroponik dengan metode Asynchronous Learning dan Dynamic Intellectual Learning: 


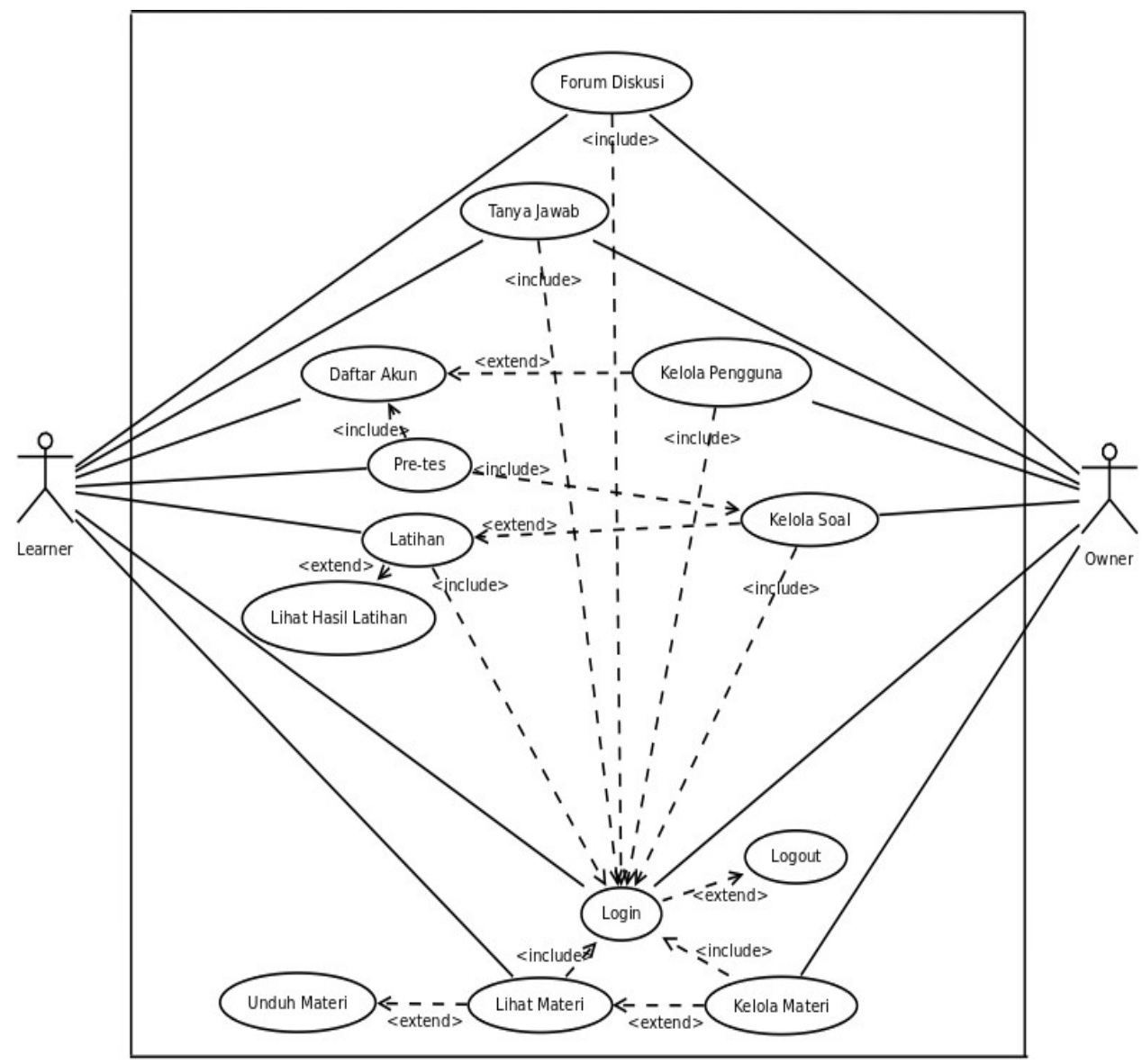

Gambar 3.2 Use Case diagram

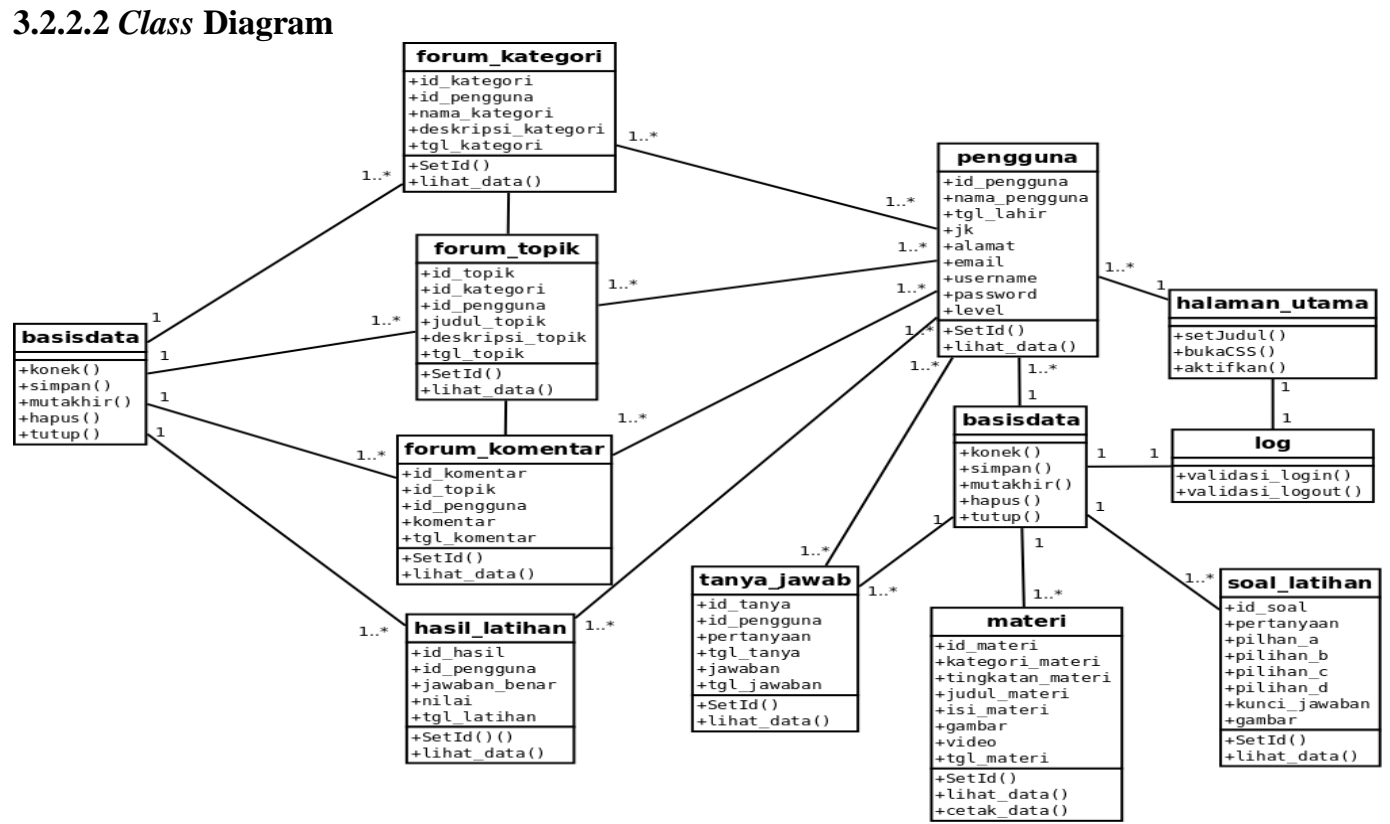

Gambar 3.3 Class diagram 


\subsubsection{Sequence Diagram}

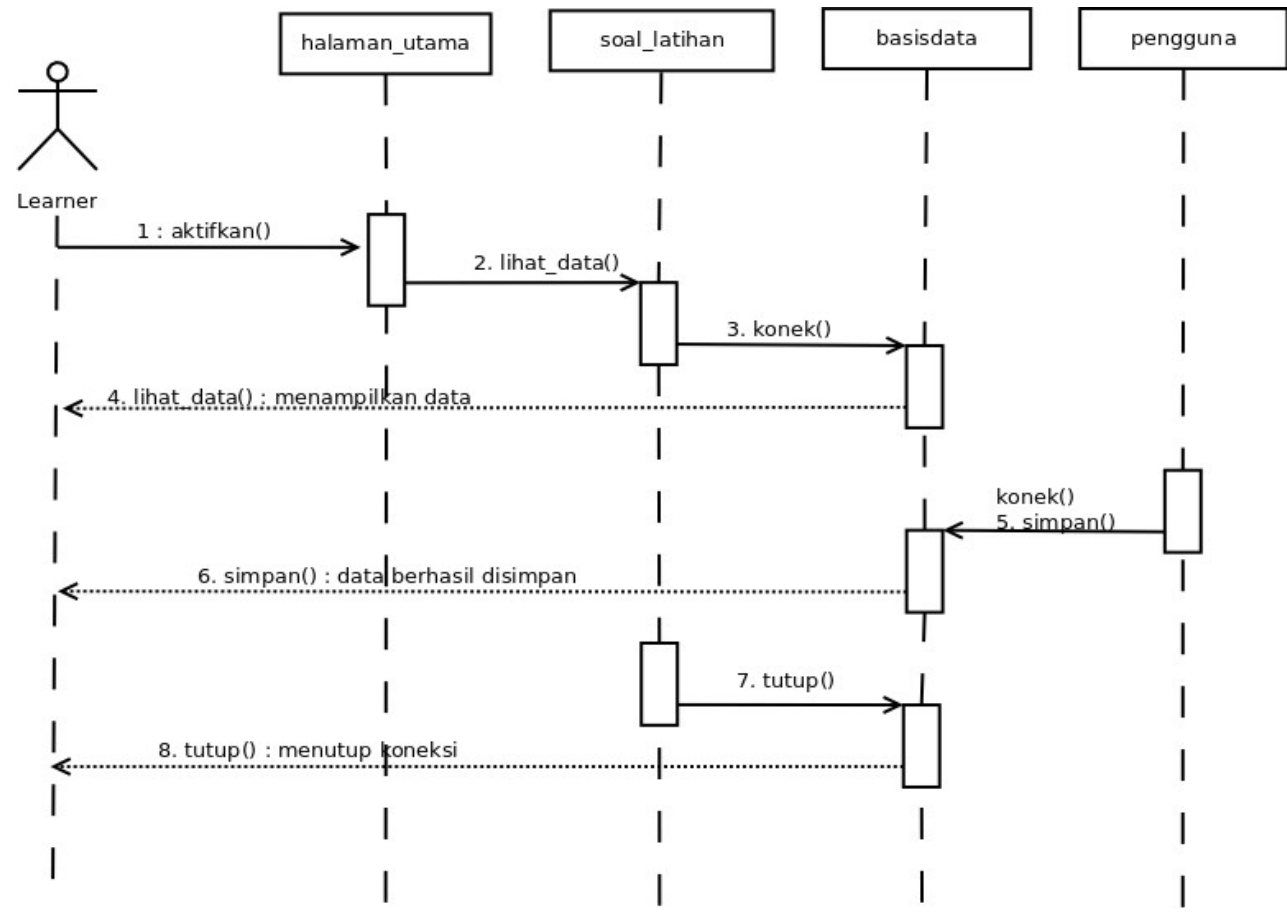

Gambar 3.4 Sequence diagram pre-tes

\subsubsection{Activity Diagram}

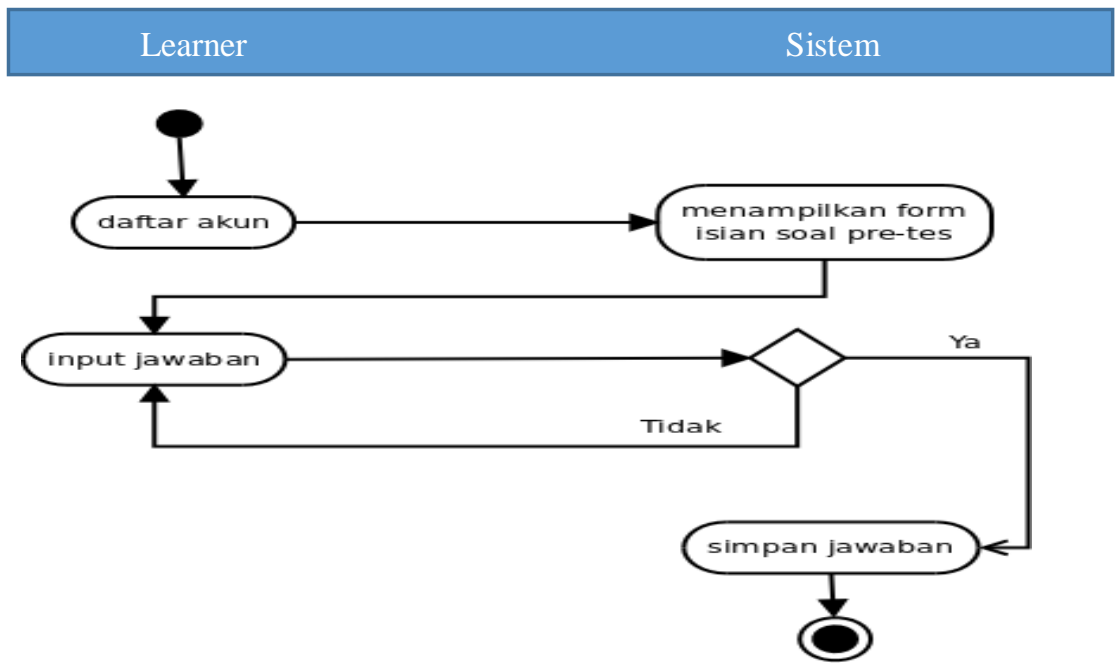

Gambar 3.5 Activity diagram pre-tes

\subsection{Design Phase}

Di dalam tahapan design, digunakan Object Oriented Design (OOD), berupa desain basisdata, desain proses, dan desain antarmuka. Berikut ini adalah rancangan desain yang akan dibangun.

\subsubsection{Desain Basisdata}

DBMS yang digunakan

Nama Basisdata
: MySQL

: learn_hydroponics 


$\begin{array}{lc}\text { Nama Tabel } & : \text { materi } \\ \text { Fields Kunci } & : \text { id_materi } \\ \text { Metode Pengurutan Data } & : \text { Ascending } \\ \text { Tipe Tabel } & : \text { Master } \\ & \text { Tabel } 3.2 \text { Tabel Materi }\end{array}$

\begin{tabular}{lllll}
\hline No. & Nama Fields & Type & Ukuran & Deskripsi \\
\hline 1. & id_materi & int & 10 & Id materi (Auto_Increment) \\
2. & kategori_materi & varchar & 20 & Kategori materi \\
3. & tingkatan_materi & varchar & 10 & Tingkatan materi \\
4. & judul_materi & text & - & Judul materi \\
5. & isi_materi & text & - & Isi materi \\
6. & gambar & text & - & Nama gambar yang disimpan \\
7. & video & text & - & Nama video yang disimpan \\
8.. & tgl_materi & datetime & - & Tanggal materi saat disimpan \\
\hline
\end{tabular}

\subsubsection{Desain Proses}

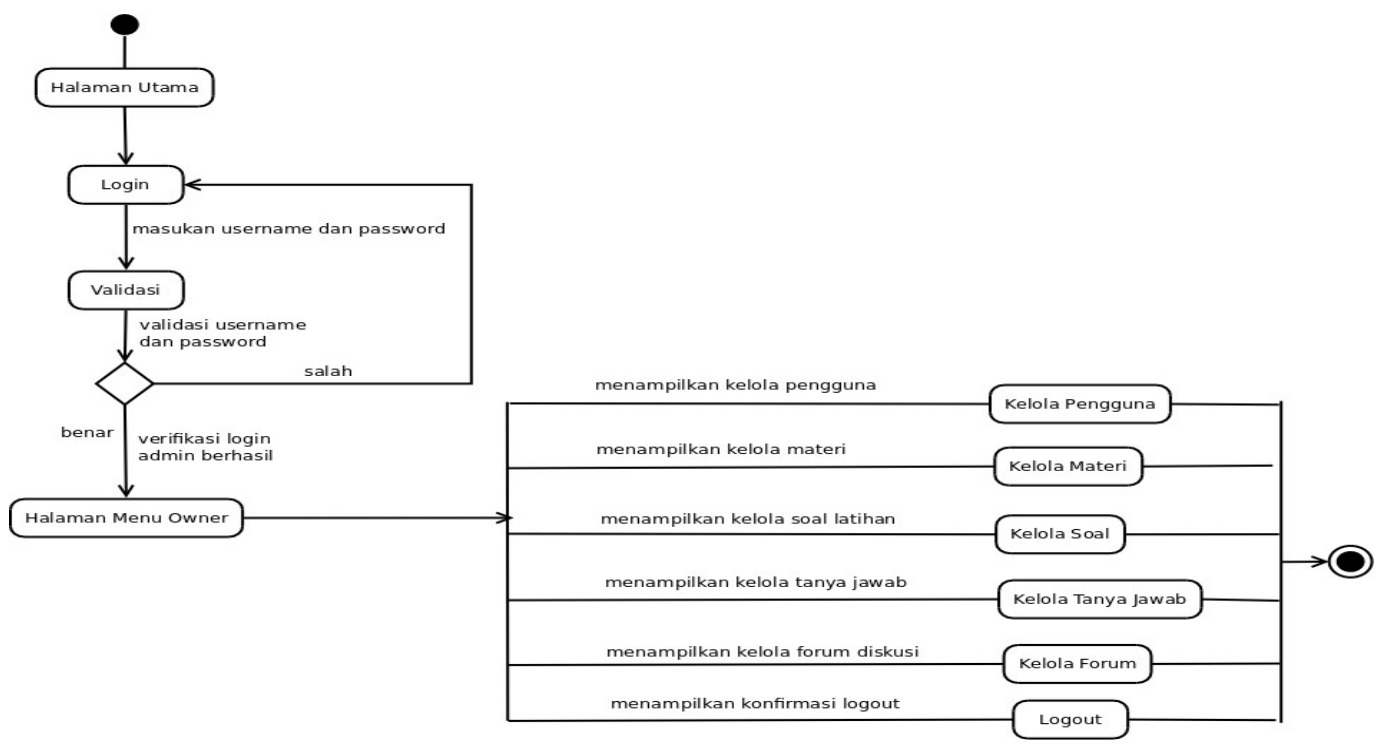

Gambar 3.6 Desain proses halaman owner pada e-learning hidroponik 


\subsubsection{Desain Antarmuka}

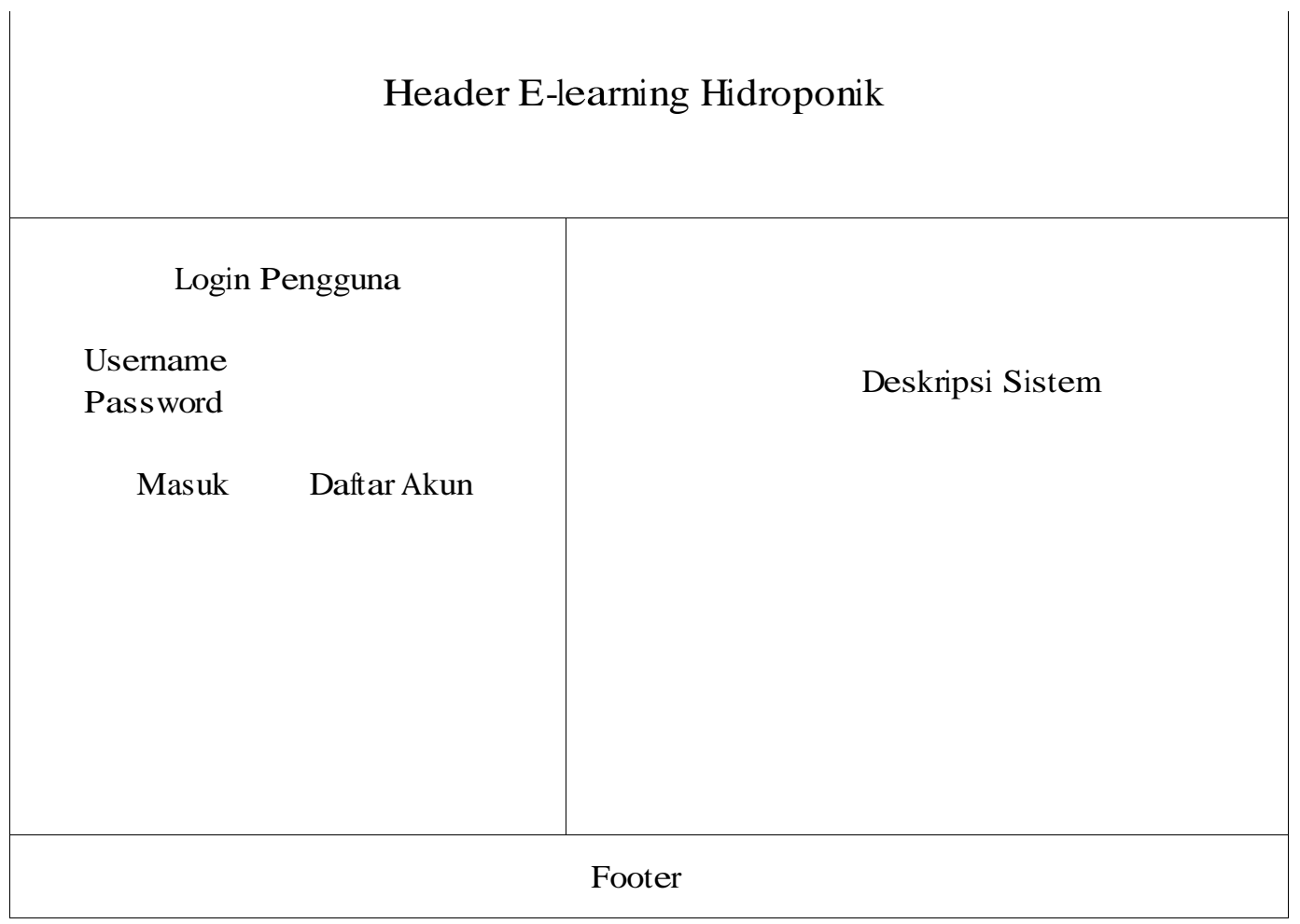

Gambar 3.7 Desain Antarmuka

\subsection{Implementaion Phase}

Di dalam tahapan ini, dilakukan proses instalasi sistem, pelatihan prosedural penggunaan sistem, dan pengujian sistem pada komputer.

\subsubsection{Instalasi Sistem}

Adapun instalasi perangkat lunak adalah Instalasi Geany, Instalasi Apache, Instalasi MySQL, Instalasi phpMyAdmin, Instalasi E-Learning Hidroponik dalam localhost

\subsubsection{Pelatihan Prosedural Penggunaan Sistem}

Adapun pelatihan prosedural penggunaan sistem yaitu mempelajari semua materi mulai dari cara membuka website, membuat username sampai dapat logout. 

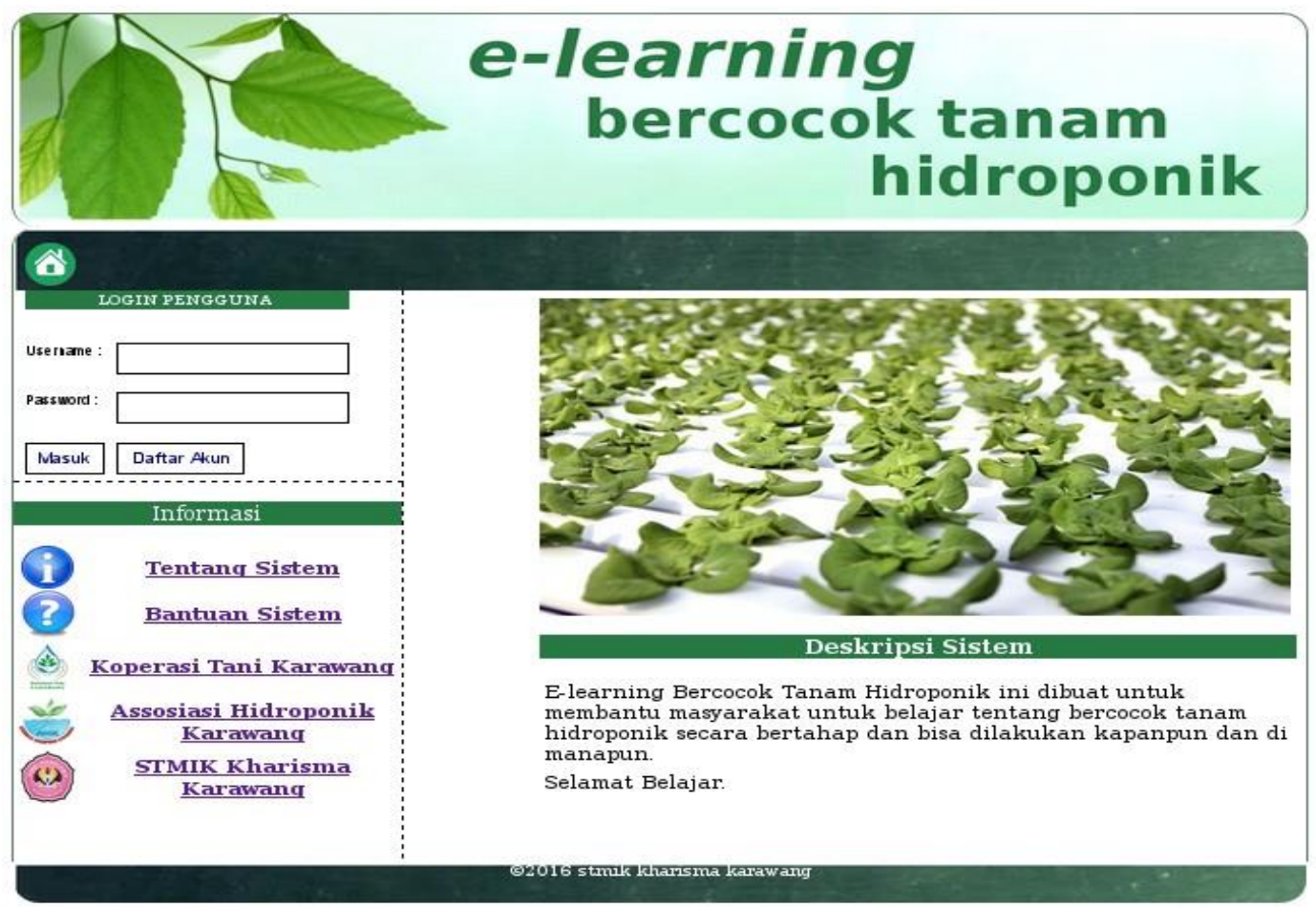

Gambar 4.1 Menu Utama

\subsubsection{Pengujian Aplikasi}

\subsubsection{Pengujian Whitebox}

White box testing merupakan pengujian yang memperhitungkan mekanisme internal sistem atau komponen.

\section{a. Cyclomatic Complexity $\mathrm{V}(\mathrm{G})$}

Perhitungan ini digunakan untuk menentukan jumlah independent path yang akan ditelusuri

$$
\begin{aligned}
\text { a. } \mathrm{V}(\mathrm{G}) & =\mathrm{R}=14 \\
\text { b. } \mathrm{V}(\mathrm{G}) & =\mathrm{E}-\mathrm{N}+2 \\
& =78-66+2 \\
& =14 \\
\text { c. } \mathrm{V}(\mathrm{G}) & =\mathrm{P}+1 \\
& =13+1 \\
& =14
\end{aligned}
$$

Keterangan :

$$
\begin{aligned}
& \mathrm{V}(\mathrm{G})=\text { jumlah maksimal independent paths } \\
& \mathrm{R} \quad \text { = jumlah regions dari alur program } \\
& \mathrm{E} \quad \text { = jumlah edge } \text { atau garis penghubung dari alur program } \\
& \mathrm{N} \quad \text { jumlah node atau simpul dari alur program } \\
& \mathrm{P} \quad \text { = jumlah decisions atau pencabangan dari alur program }
\end{aligned}
$$

\subsubsection{Pengujian Blackbox}

Blackbox testing adalah pengujian yang dilakukan hanya mengamati hasil eksekusi melalui data uji dan memeriksa fungsional dari perangkat lunak.

Tabel 4.1 Tabel pengujian blackbox

\begin{tabular}{|l|l|l|l|l|c|}
\hline No & Nama Fungsi & Kriteria & \multicolumn{2}{|c|}{ Hasil Test } & \multirow{2}{*}{ Ket } \\
\cline { 4 - 5 } & & & User 1 & User 2 & \\
\hline 1 & Login & Akurat, kemudahan penggunaan, & Ok & Ok & \\
\hline
\end{tabular}




\begin{tabular}{|c|c|c|c|c|}
\hline & & pengujian operasional & & \\
\hline 2 & KelolaPengguna & $\begin{array}{l}\text { Akurat, kemudahan penggunaan, } \\
\text { pengujian operasional }\end{array}$ & Ok & Ok \\
\hline 3 & KelolaMateri & $\begin{array}{l}\text { Akurat, kemudahan penggunaan, } \\
\text { pengujian operasional }\end{array}$ & Ok & Ok \\
\hline 4 & Forum Diskusi & $\begin{array}{l}\text { Akurat, kemudahan penggunaan, } \\
\text { pengujian operasional }\end{array}$ & Ok & Ok \\
\hline 5 & Tanya Jawab & $\begin{array}{l}\text { Akurat, kemudahan penggunaan, } \\
\text { pengujian operasional }\end{array}$ & Ok & Ok \\
\hline 6 & Kelola Soal & $\begin{array}{l}\text { Akurat, kemudahan penggunaan, } \\
\text { pengujian operasional }\end{array}$ & Ok & Ok \\
\hline 7 & Latihan & $\begin{array}{l}\text { Akurat, kemudahan penggunaan, } \\
\text { pengujian operasional }\end{array}$ & Ok & Ok \\
\hline 8 & $\begin{array}{l}\text { Lihat Hasil } \\
\text { Latihan }\end{array}$ & $\begin{array}{l}\text { Akurat, kemudahan penggunaan, } \\
\text { pengujian operasional }\end{array}$ & Ok & Ok \\
\hline 9 & Pre-test & $\begin{array}{l}\text { Akurat, kemudahan penggunaan, } \\
\text { pengujian operasional }\end{array}$ & Ok & Ok \\
\hline 10 & Lihat Materi & $\begin{array}{l}\text { Akurat, kemudahan penggunaan, } \\
\text { pengujian operasional }\end{array}$ & Ok & Ok \\
\hline 11 & Unduh Materi & $\begin{array}{l}\text { Akurat, kemudahan penggunaan, } \\
\text { pengujian operasional }\end{array}$ & Ok & Ok \\
\hline 12 & Daftar Akun & $\begin{array}{l}\text { Akurat, kemudahan penggunaan, } \\
\text { pengujian operasional }\end{array}$ & Ok & Ok \\
\hline 13 & Logout & $\begin{array}{l}\text { Akurat, kemudahan penggunaan, } \\
\text { pengujian operasional }\end{array}$ & Ok & Ok \\
\hline
\end{tabular}

\subsection{Support Phase}

Aktifitas yang dilakukan dalam tahapan ini adalah maintenance system untuk memperbaiki kesalahan/bug dalam aplikasi yang dibuat, enhance system dengan menambah fitur-fitur yang sekiranya diperlukan di masa yang akan datang.

\subsection{Kesimpulan}

Dengan adanya e-learning bercocok tanam hidroponik untuk mempermudah masyarakat dalam bercocok tanam hidroponik yang baik dan benar, penulis mengambil beberapa kesimpulan :

1. E-Learning bercocok tanam hidroponik dikembangkan atau dibangun dengan metode Asynchronous Learning untuk dapat dimanfaatkan sebagai media pembelajaran yang membantu masyarakat dalam mendapatkan pembelajaran hidroponik, dalam mengakses materi pembelajaran learner tanpa harus datang pada tempat pelatihan atau pembelajaran, serta mendapat materi pembelajaran pada waktu yang tidak bersamaan dengan pengajar dalam memberikan materi pembelajaran, cukup hanya dengan membuka akses pada e-learning hidroponik ini. 
2. E-learning bercocok tanam hidroponik ini juga mengguanakan metode Dynamic Intellectual Learning yang memiliki tiga tingkatan kemampuan yaitu tingkat dasar, tingkat memulai, dan tingkat lanjutan yang ditujukan untuk membantu masyarakat dalam mendapatkan pembelajaran hidroponik secara bertahap dari mulai pengenalan sistem hidroponik, sampai dengan tahap budidaya serta rancangan bisnis hidroponik.

3. E-learning bercocok tanam hidroponik ini diimplementasikan:

a. Dengan metode Asynchronous Learning, dimana learner dapat mengakses materi tanpa waktu yang bersamaan dengan instruktur/pengajar dalam memberikan materi pembelajaran, serta disediakan latihan dalam bentuk kuis sederhana untuk mengukur sejauh mana pemahan materi yang diberikan, dan disediakan pula sebuah forum diskusi untuk berdiskusi dengan pengguna lainya.

b. Dengan metode DynamicIntellectual Learning, dimana dalam pembelajarannya learner dibagi dalam tiga tahapan/tingkatan materi, materi yang diberikan tersebut dimulai dari tingkatan dasar yang berisi

\section{DAFTAR PUSTAKA}

Alatas, Putri, 2009, "Implementasi Teknik Steganography dengan Metode LSB pada Citra Digital". Universitas Gunadarma.

Ariyus, Deny, 2009, "Keamanan Multimedia", Yogyakarta, ANDI.

Hapsari, Dian, Dwi dan Bonowosari, Yuniar, Lintang, "Aplikasi Vide teganography dengan Metode least significant bit $(l s b)$.

Noertjahyana, Agustinus, Hartono, Samuel, dkk. "Aplikasi Metode Steganography Pada Citra Digital Dengan Menggunakan Metode LSB (Least Significant Bit).

Jalid , Abdul, Alfian. "Aplikasi Pengamanan Data dan Informasi dengan Metode Steganografi LSB dan Algoritma Kriptografi Tripledes Menggunakan Bahasa Pemrograman C\#”.

Perdamean, Agus. "Implementasi Steganography Algoritma Elgamal dan Digital Signature Untuk Pengamanan Data Pada CV. Tridian Hariwangsa Palembang”. 
TechnoXplore

Jurnal Ilmu Komputer \& Teknologi Informasi
ISSN : 2503-054X

Vol 2 No:1, April 2017 